\title{
SEASONAL EFFECT IN ESSENTIAL OIL COMPOSITION AND ANTIOXIDANT ACTIVITY OF Plectranthus amboinicus LEAVES
}

\author{
EFEITO SAZONAL NA COMPOSIÇÃO E ATIVIDADE ANTIOXIDANTE DO ÓLEO \\ ESSENCIAL DE MALVARISCO (Plectranthus amboinicus)
}

\section{Rita de Cássia de Freitas BEZERRA; Francisco Barros de OLIVEIRA NETO²; Francisco Felipe Maia da SILVA ${ }^{3}$; Luciana Medeiros BERTINI Leonardo Alcântara ALVES ${ }^{4}$}

1. Mestranda do Programa de Pós-graduação em Energias Renováveis - IFCE, Instituto Federal de Educação, Ciência e Tecnologia do Ceará, Macaranaú, CE, Brasil; 2. Graduado em Licenciatura Plena em Química, Instituto Federal de Educação, Ciência e Tecnologia do Rio Grande do Norte - IFRN, Apodi, RN, Brasil; 3. Docente do curso de Licenciatura Plena em Química - IFRN, Apodi, RB, Brasil; 4.

Docentes do Programa de Pós-graduação em Ensino (POSENSINO), em associação ampla entre a Universidade do Estadual do Rio Grande do Norte - UERN, Universidade Federal do Semi-Árido - UFERSA e IFRN, Apodi, RN, Brasil. leonardo.alcantara@ifrn.edu.br

\begin{abstract}
In view of the increasing search for natural products with biological activities, such as essential oils are of high quality because of their therapeutic and economic importance and represent the second class of natural compounds with the largest number of active constituents and production through Plants minimizes the environment and sanitary impacts. The objective of the present work is to assess the seasonal effect on the composition and antioxidant activity of essential oil in leaves of Plectranthus amboinicus (Lour.) Spreng using hydro and steam distillation techniques. With regarding to the extraction methodology of essential oils from the $P$. amboinicus, the hydrodistillation technique is the most efficient in obtaining the volatile product with the best features for the determination of antioxidant activity. The analyses of the essential oil indicated a similarity in their composition, being observed the Carvacrol as major compound in almost all analysis, except in January 2015 using steam distillation extraction. Regarding antioxidant activity and seasonality, it was verified that in October 2014 obtained the best value of inhibitory concentration, with $\mathrm{IC}_{50}=124.97$ ppm. However, it was possible to obtain the essential oil from the P. amboinicus leaves through hydro and steam distillation methodologies, but also noted the seasonality influence on it's the context of antioxidant capacity.
\end{abstract}

KEYWORDS: Antioxidant activity. P. amboinicus. Extraction methods. Essential oil. Seasonal

\section{INTRODUCTION}

It is known that the use of plants for therapeutic purposes began thousands of years ago and, currently, this usage has been intensifying, even with advances in medicinal drug. This is because these natural medicines are bringing positive results to the population that seeks in these products an alternative healing and disease prevention.

Inserted in this context, Brazil gains prominence because it presents a large and diverse flora, besides having the largest equatorial and tropical rain forest on the planet, making it a good location for the exploitation of natural products. The Natural Products Chemistry (NPC) is, within the chemistry, the oldest area and that groups the largest number of researchers (PINTO et al., 2002).

However, it is important the development of research that seek isolation, characterization and identification of these compounds present in plants with medicinal properties and pharmacological activities. Thus, it is noticed the importance of multidisciplinary research that aggregate their chemical, microbiological, pharmacological, and biotechnological knowledges (FOGLIO et al., 2006).

Among these studies, it can be cited the determination of the chemical composition from the essential oils and volatile compounds obtained from plants and animals. The aforementioned show great relevance in industrial, medicinal, and other areas, because they are potentially useful in phytosanitary control, resulting in the development of techniques that seek to reduce the negative effects of oxidants, radicals, and microorganisms that cause losses in the food industries and in agriculture (BAKKALI et al., 2008; MATTEI et al., 2014).

Antioxidants can be defined as those that inhibit and/or reduce the effects triggered by free radicals and oxidant compounds in oxidable substrates. These substances can be enzymatic, such as superoxide dismutase, catalase, and glutathione peroxidase, or not enzymatic, such as $\alpha$-tocopherol (vitamin $\mathrm{E}$ ), $\beta$-carotene, ascorbate (vitamin $\mathrm{C}$ ), and phenolic compounds (HALLIWELL, 2001). It is remarkable that research with interest in finding natural antioxidants that may be used in food products or with pharmaceutical purposes have increased significantly. This occurs due to the 
intention to replace the synthetic antioxidants that, in turn, have shown their limited use due to the carcinogenic potential (ALMEIDA et al., 2006; MELO; GUERRA, 2002; SIMÃO, 1985; ZHENG; WANG, 2001).

In this way, the essential oils are being increasingly studied as antioxidant agents, in an attempt to spur the development of techniques that seek to reduce the negative effects of oxidative substances (SANTOS, 2004).

Ruberto and Baratta (2000), in their work with approximately 100 compounds that compose the essential oils, found that, in general, their antioxidant activity may be relevant when associated with phenolic components, followed by the oxygenated constituents and allyl alcohols present in their composition. However, many studies have reported the antioxidant properties of essential oils, referring to them as potential substitutes for synthetic antioxidants and, in some cases, suggesting them to a direct application in food, farming, pharmaceutical and cosmetic products (ANDRADE et al., 2012).

In this sense, the genus Plectranthus (L'Her.), from the family Lamiaceae, is considered one of the richest in essential oils, having as main constituents the mono- and sesquiterpenes (ABDEL-MOGIB et al., 2002). From the 300 species of the genus Plectranthus already identified, 62 are mentioned because they have medicinal, food, flavoring, antiseptic, and repellent properties, besides for using as pastures and as ornamental plants (LUKHOBA; SIMMONDS; PATON, 2006).

Plectranthus amboinicus (Fig. 1), also known as Indian borage, is a medium-sized herb, whose leaves are used in the preparation of homemade syrups for treating cough, sore throat and bronchitis, and in the treatment of wounds caused by cutaneous leishmaniasis. The juice of the leaves is used to treat ovarian and uterine problems, including cases of cervicitis (LORENZI; MATOS, 2002; COSTA, 2003). Figure 1 shows the plant species $P$. amboinicus.

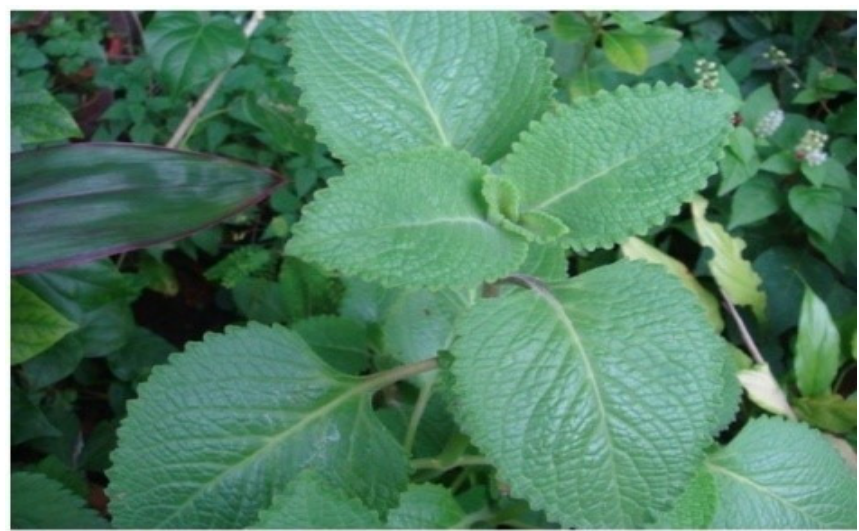

Figure 1. Plant species Plectranthus amboinicus

Thereby, this study aimed to perform seasonal extraction of the essential oil present in leaves of $P$. amboinicus (Lour.) Spreng using hydro and steam distillation techniques, as well as to evaluate the influence of the seasonal effect in determining the composition and antioxidant activity of the obtained volatile oil.

\section{MATERIAL AND METHODS}

\section{Plant Material}

The plant material was cultivated and collected in Instituto Federal de Educação, Ciência e Tecnologia do Rio Grande do Norte (IFRN), Apodi, RN, Brazil (05'37'34' S, 37\%48'34' W). The leaves of $P$. amboinicus were initially ground and then weighted. Essential oil extraction was performed from April 2014 to January 2015, being the plant material always collected in the morning every three months.

\section{Hydrodistillation Extraction}

The essential oil was extracted from $450 \mathrm{~g}$ of the ground plant material, which was placed in a round-bottom flask containing approximately $1 \mathrm{~L}$ of distilled water and, subsequently, maintained for $2 \mathrm{~h}$ uninterrupted in boiling, using a distiller of Clevenger-type. The essential oil was separated by decantation, dried with anhydrous sodium sulfate $\left(\mathrm{Na}_{2} \mathrm{SO}_{4}\right)$, weighted and collected in amber vials. The material was stored in a freezer for chemical analysis.

\section{Steam Distillation Extraction}

A total of $1.0 \mathrm{~kg}$ of $P$. amboinicus leaves were ground and placed in extractor (SILVA et al., 
2014), containing $10 \mathrm{~L}$ of distilled water. The material was heated for $4 \mathrm{~h}$ uninterrupted. The essential oil was separated by decantation, collected, dried with anhydrous sodium sulfate $\left(\mathrm{Na}_{2} \mathrm{SO}_{4}\right)$ and weighted. The material was stored in a freezer for chemical analysis.

\section{Chemical Analysis Of The Essential Oil}

The oil samples were analyzed in a gas chromatography Shimadzu model KP 5050A coupled to a mass detector using a DB-1 capillary column $(30 \mathrm{~m} \times 0.25 \mathrm{~mm}$, i.d. $\times 0.25 \mu \mathrm{m}$ film thickness) in the following: carrier gas hydrogen flow rate $1.7 \mathrm{~mL} / \mathrm{min}$ and with split mode at ratio $1: 27$, ion source temperature $280^{\circ} \mathrm{C}$, ionizations voltage $70 \mathrm{eV}$, electron impact detection. The thermal conditions of the column were from $40^{\circ} \mathrm{C}$ to $180^{\circ} \mathrm{C}$ at $4^{\circ} \mathrm{C} / \mathrm{min}$ and then $180^{\circ} \mathrm{C}$ to $280^{\circ} \mathrm{C}$ at $20^{\circ} \mathrm{C} / \mathrm{min}$, and held isothermal for $7 \mathrm{~min}$.

The essential oils were analyzed by GC-MS and individual components was identified comparing the mass spectrum obtained with the Wiley library, simulation of the Kovat index (ALENCAR et al., 1990), as well as visual comparison with the standard of fragmentation of spectra of mass described in the literature (ADAMS, 2007) and the database provided with the mass spectra (SciFinder).

\section{Antioxidant Activity}

The evaluation of the antioxidant capacity of the essential oils from the leaves of $P$. amboinicus was performed through the capture method of DPPH radicals (2,2-diphenyl-1picrylhydrazyl) described by Cosmoski et al. (2015) with alterations. It was weighted $0.01 \mathrm{~g}$ of the volatile oil diluted in $10 \mathrm{~mL}$ of methanol. From this, solutions of 1000, 500, 100, 50, and $10 \mathrm{ppm}$ were prepared. A rate of $1.0 \mathrm{~mL}$ from each solution was removed and added into test tubes containing 1.0 $\mathrm{mL}$ of methanolic solution of DPPH $60 \mu \mathrm{M}$. The solutions were left at room temperature and in the absence of light for 30 minutes. Readings were performed in spectrophotometer UV TEN-KA T2000 at $520 \mathrm{~nm}$ wavelength, having as white a solution containing $1.0 \mathrm{~mL}$ methanol and $1.0 \mathrm{~mL}$ DPPH solution. All analyses were performed in triplicate, as for the essential oil obtained by hydrodistillation as for steam distillation method. The inhibition percentage (\%In) for each sample was obtained from the use of the absorbance values:

$$
\% \text { In }=\frac{\text { Abs. DPPH }- \text { Abs. sample }}{\text { Abs. DPPH }} \times 100 \%
$$

Where:

$\%$ In: Inhibition percentage of the extract.

Abs. DPPH: Absorbance obtained with sample DPPH/methanol.

Abs. sample: Absorbance obtained from sample.

\section{RESULTS AND DISCUSSION}

After the completion of seasonal extraction of essential oil from the leaves of $P$. amboinicus, using the methods of hydro and steam distillation, it was possible to obtain the efficiency of each oil, described in Table 1. Efficiencies were calculated by the ratio between the weights of obtained oil and the fresh plant material.

Table 1. Efficiency of the essential oil from the leaves of P. amboinicus obtained in different methods and periods

\begin{tabular}{lcc}
\hline & \multicolumn{2}{c}{ Extraction methods /Obtained efficiency (\%) } \\
\cline { 2 - 3 } Months & Hydrodistillation & Steam distillation \\
\hline April 2014 & 0.0512 & 0.0046 \\
July 2014 & 0.2371 & 0.0109 \\
October 2014 & 0.0386 & 0.0066 \\
January 2015 & 0.0117 & 0.0022 \\
\hline
\end{tabular}

According to Table 1, for the analyzed methods, hydrodistillation showed the highest essential oil content. With regard to the month, July 2014 obtained the best efficiency of the essential oil from the leaves of $P$. amboinicus in both extraction methods, $0.2371 \%$ in hydrodistillation and $0.0109 \%$ in steam distillation.
In studies conducted by Bandeira et al. (2011), Oliveira et al. (2011) and Rodrigues et al. (2013) were obtained $0.19 \%, 0.43 \%$, and $0.3 \%$, respectively, using hydrodistillation as extraction method. According to Reis (2012), the extraction conditions are determining factors for the efficiency, chemical composition and quality of essential oil. 
Concerning the composition of the essential oil (Table 2), the Carvacrol is the major component in leaves of $P$. amboinicus during almost the entire year, especially April 2014, showing a level of 73.4\%. Only in January 2015, using the steam distillation technique, it was not possible to identify the Carvacrol as major substance. With regard to the most efficient methodology to obtain the essential oil from the leaves of $P$. amboinicus, it is reaffirmed that the hydrodistillation method proved to be more effective, since in the referred methodology the major constituent appeared in higher concentrations in all extraction periods.

However, from the seasonal extraction of essential oil from leaves of $P$. amboinicus, as well as the characterization and quantification of their constituents, it was verified that there is a similarity in their chemical composition, showing some changes in different periods. In addition, it was possible to observe that the chemical composition of the essential oil from the leaves of $P$. amboinicus can be characterized both by the extraction method and by the period in which the same was realized.

The antioxidant capacity of essential oils obtained by the methods of hydro and steam distillation were evaluated according to the capture method of radicals 2,2-diphenyl-1-picrylhydrazyl (DPPH), proposed by Cosmoski et al. (2015). The values of $\mathrm{IC}_{50}$ for each essential oil are described in Table 3.

It was verified that the hydrodistillation technique resulted in a better antioxidant capacity. In the referred extraction methodology, in the months of April 2014 and October 2014, the best values were obtained of $\mathrm{IC}_{50}, 132.6$ and $125.0 \mathrm{ppm}$, respectively. It is noteworthy that these were the months where the largest concentrations of Carvacrol were observed. Furthermore, only in the month of July 2014 was not observed significant antioxidant activity for the essential oils obtained from this method. It was noted that in the month of January 2015 the worst values of inhibitory concentrations with $\mathrm{IC}_{50}=352.1 \mathrm{ppm}$ in hydrodistillation and $595.0 \mathrm{ppm}$ in steam distillation.

It is proved that the harvest season can influence the efficiency and composition of essential oil in plants. Several studies report the physiological reactions of the plant metabolism due to climatic aspects: time of year and their characteristics associated with rates of temperature, rainfall and humidity. It is important to point out that there is a positive correlation between well-established intensity of solar radiation and the production of phenolic compounds. The different plant species are adapted to a huge variation in the intensity and quantity of light incidence (GOBBO NETO; LOPES, 2007).

Andrade et al. (2012), when examining the antioxidant capacity of the essential oils of Cymbopogon nardus (citronella grass), Cinnamomum zeylanicum (true cinnamon), and Zingiber officinale (ginger), using the same methodology of this research obtained the results below. For the citronella grass, the inhibitory concentration value was $517.4 \mathrm{ppm}$ and significant antioxidant activity was not observed for the essential oils of true cinnamon and ginger.

Therefore, from the values found in this research, it can be affirmed that the essential oil from the leaves of $P$. amboinicus presents a good antioxidant capacity when compared to other oils. However, the period and the extraction method of volatile oil are crucial for better inhibitory concentrations. 
Table 2. Seasonal analysis of the chemical composition of the essential oil of $P$. amboinicus by steam and hydrodistillation

\begin{tabular}{|c|c|c|c|c|c|c|c|c|}
\hline \multirow[b]{2}{*}{ Months } & \multicolumn{4}{|c|}{ Steam distillation } & \multicolumn{4}{|c|}{ Hydrodistillation } \\
\hline & April 2014 & July 2014 & October 2014 & January 2015 & April 2014 & July 2014 & October 2014 & January 2015 \\
\hline Compound & \multicolumn{4}{|c|}{ Content (\%) } & \multicolumn{4}{|c|}{ Content (\%) } \\
\hline Isoterpinolene & 0.3 & - & - & - & - & - & - & - \\
\hline$p$-Cimene & 6.1 & - & - & - & - & - & - & - \\
\hline$\gamma$-Terpinene & 9.6 & 4.6 & - & - & 7.1 & 5.4 & 3.9 & - \\
\hline Terpinen-4-ol & 0.5 & - & - & - & 1.4 & - & - & - \\
\hline Carvacrol & 27.3 & 40.0 & 34.0 & - & 73.4 & 46.8 & 68.1 & 48.0 \\
\hline Caryophyllene & 26.1 & 17.2 & 19.1 & - & 4.9 & 4.3 & 8.1 & - \\
\hline$\alpha$-Bergamotene & 16.3 & 11.7 & 16.1 & - & - & 2.4 & 5.3 & - \\
\hline Humulene & 7.1 & - & - & - & 1.4 & - & - & - \\
\hline Caryophyllene oxide & 3.8 & 2.5 & 7.9 & 3.5 & 1.0 & 1.1 & 2.6 & 9.4 \\
\hline Phytol & 0.2 & - & 1.1 & - & - & - & - & - \\
\hline$\beta$-Myrcene & - & 0.3 & - & - & 0.5 & - & - & - \\
\hline$\alpha$-Terpinene & - & - & - & - & 1.1 & - & - & - \\
\hline o-Cymene & - & 4.2 & - & - & 5.1 & 6.5 & 4.9 & - \\
\hline Sec-butyl acetate & - & 0.2 & - & 1.0 & - & - & - & - \\
\hline Isobutyl acetate & - & 6.4 & - & 30.0 & - & 18.3 & - & 15.3 \\
\hline$o$-xylene & - & 0.7 & - & - & - & 1.8 & - & - \\
\hline$\alpha$-cytral & - & 1.1 & 2.4 & - & - & - & - & - \\
\hline$\alpha$-caryophyllene & - & 4.8 & 6.2 & - & - & 1.0 & 2.4 & - \\
\hline$\beta$-bisabolene & - & 0.7 & - & - & - & - & - & - \\
\hline n-decane & - & - & - & - & - & 0.7 & - & - \\
\hline (+)-4-carene & - & - & - & - & - & 0.9 & - & - \\
\hline
\end{tabular}


Seasonal effect in essential..

\section{$\beta$-cytral}

4-terpineol

Tridecanone

Isopentyl

Toluene

$m$-xylene

(+) - Spathulenol

Pentadecane-2-one

1,2-Benzenedicarboxylic

acid

Cedrol

Total Monoterpenes

Total Sesquiterpenes

Total Diterpenes

43.8

53.3

0.2

Others

Totalcomposition (\%)
BEZERRA. R. C. F. et al

$\begin{array}{lll}- & 1.2 & - \\ - & - & - \\ - & 2.5 & - \\ - & - & 1.3 \\ - & - & 41.6 \\ - & - & 1.3 \\ - & - & 1.9 \\ - & - & 1.5 \\ - & - & 6.0 \\ - & & \\ 50.2 & - & 1.3 \\ 36.9 & 37.6 & - \\ - & 49.3 & 6.7 \\ 7.3 & 1.1 & - \\ \mathbf{9 4 . 4} & 2.5 & 82.7 \\ & \mathbf{9 0 . 5} & \mathbf{8 9 . 4}\end{array}$

$\begin{array}{lll}- & 2.0 & - \\ - & - & - \\ - & - & - \\ - & - & 20.6 \\ - & - & 0.7 \\ - & - & - \\ - & - & - \\ - & - & - \\ - & & - \\ 59.6 & - & 48.0 \\ 8.8 & 78.9 & 9.4 \\ - & 18.4 & - \\ 20.8 & - & 36.6 \\ \mathbf{8 9 . 2} & - & \mathbf{9 4 . 0}\end{array}$


Table 3. Antioxidant activity obtained by DPPH method of the essential oils from the leaves of P. amboinicus

\begin{tabular}{ccc}
\hline & \multicolumn{2}{c}{ Extraction methods / IC $\mathbf{5 0}(\mathbf{p p m})$} \\
\cline { 2 - 3 } Months & Hydrodistillation & Steam distillation \\
\hline April 2014 & 132.6 & 309.4 \\
July 2014 & NI & NI \\
October 2014 & 125.0 & NI \\
January 2015 & 352.1 & 595.0 \\
$\mathrm{IC}_{50}=$ inhibiting concentration 50\%; NI = not present inhibition &
\end{tabular}

\section{CONCLUSIONS}

As regards the extraction methodology of essential oils from the leaves of $P$. amboinicus, the hydrodistillation technique is the most efficient in obtaining the volatile product by offering better efficiency and antioxidant activity. However, it is important to note that the extractions performed by steam distillation, despite the values found are lower than those of hydrodistillation, are considered satisfactory when compared to other works from literature.

It was also verified that the Carvacrol might be the main compound that influences the antioxidant activity of studied oil.

RESUMO: Tendo em vista a crescente busca de produtos naturais com atividades biológicas, os óleos essenciais apresentam alta qualidade devido à sua importância terapêutica e econômica e representam a segunda classe de compostos naturais com o maior número de constituintes ativos com produção através das plantas, o que minimiza os impactos ao meio ambiente. O objetivo do presente trabalho foi avaliar o efeito sazonal na composição e na atividade antioxidante do óleo essencial presente nas folhas da Plectranthus amboinicus (Lour.) Spreng utilizando as técnicas de hidrodestilação e arraste a vapor d'água. No que se refere à metodologia de extração dos óleos essenciais do malvarisco, constatou-se que a técnica de hidrodestilação é a mais eficiente na obtenção do produto volátil com as melhores características para a determinação da atividade antioxidante. Quanto à sazonalidade, verificou-se que no mês de Outubro/2014 obteve-se o melhor valor da concentração inibitória com $\mathrm{CI}_{50}=124,97 \mathrm{ppm}$. Este trabalho mostra que é a obtenção do óleo essencial das folhas do malvarisco, utilizando as metodologias de hidrodestilação e arraste a vapor de água, como também, constatar a influência da sazonalidade na determinação da capacidade antioxidante do mesmo.

PALAVRAS-CHAVE: Atividade antioxidante. P. amboinicus. Métodos de extração. Óleo essencial. Sazonal

\section{REFERENCES}

ABDEL-MOGIB, M.; ALBAR, H. A.; BATTERJEE, S. M. Chemistry of the genus Plectranthus. Molecules, v.7, p.271-301, 2002. https://doi.org/10.3390/70200271

ADAMS, R. P. Identification of essential oils components by gas chromatography mass spectroscopy. 4th, Allured Pubishing Corporation, Carol Stream, Illinois, USA, 2007. 804 p.

ALENCAR, J. W.; CRAVEIRO, A. A.; MATOS, F. J. A.; MACHADO, M. I. L. Kovat's indices simulation in essential oils analysis. Química Nova, v. 13, p. 282-284, 1990.

ALMEIDA, J. M. D.; SANTOS, R, J.; GENOVESE, M. I.; LAJOLO, F. M. Avaliação da atividade antioxidante utilizando sistema ß-caroteno/ácido linoléico e método de sequestro de radicais DPPH. Ciência e Tecnologia de Alimentos, v. 26, n. 2, p. 446-452, 2006. https://doi.org/10.1590/S0101-20612006000200031

ANDRADE, M. A.; CARDOSO, M. G.; BATISTA, L. R.; MALLET, A. C. T.; MACHADO, S. M. F. Óleos essenciais de Cymbopogon nardus, Cinnamomum zeylanicum e Zingiber officinale: composição, atividades antioxidante e antibacteriana. Revista Ciência Agronômica, v. 43, p. 399-408, 2012. https://doi.org/10.1590/S1806-66902012000200025 
BAKKALI, F.; AVERBECK, S.; AVERBECK, D.; IDAOMAR, M. Biological effects of essential oils - A review. Food and Chemical Toxicology. v. 46, p. 446-475, 2008. https://doi.org/10.1016/j.fct.2007.09.106

BANDEIRA, J. M.; BARBOSA, F. F.; BARBOSA, L. M. P.; RODRIGUES, I. C. S.; BACARIN, M. A.; PETERS, J. A.; BRAGA, E. J. B. Composição do óleo essencial de quatro espécies do gênero Plectranthus. Revista Brasileira de Plantas Medicinais, v. 13, n. 2, p. 157-164, 2011. https://doi.org/10.1590/S151605722011000200006

COSMOSKI, A. C. O. F.; ROEL, A. R.; PORTO, K. R. A.; MATIAS, R.; HONER, M. R.; MORRI, P. R. Phytochemistry and larvicidal activity of Spermacoce latifolia AUBL. (Rubiaceae) in the control of Aedes aegypti L. (Culicidae). Bioscience Journal, v. 31, n. 5, p. 1512-1518, 2015. https://doi.org/10.14393/BJv31n5a2015-26333

COSTA, M. C. C. D. Uso popular e ações farmacológicas de Plectranthus barbatus Andr. (Lamiaceae): revisão dos trabalhos publicados de 1970 a 2003. Revista Brasileira de Plantas Medicinais, v. 8, n. 2, p. 81-88, 2003.

FOGLIO M. A.; QUEIROGA C. L.; SOUSA I. M. O.; RODRIGUES R. A. F. Plantas medicinais como fonte de recursos terapêuticos: um modelo multidisciplinar. Revista Multidisciplinar, v. VII, 2006. Disponível em: <https://www.multiciencia.unicamp.br/art04_7.htm> Acesso em: 10 jan. 2016.

GOBBO NETO, L.; LOPES, N. P. Plantas medicinais: fatores de influência no conteúdo de metabólitos secundários. Química Nova. n. 30, p. 374-381, 2007. https://doi.org/10.1590/S0100-40422007000200026

HALLIWELL, B. Free radicals and other reactive species in disease. In: CULLEN, K. Encyclopedia of Life Sciences. London: Nature Publishing Group., p.1-7, 2001.

LORENZI, H.; MATOS, F. J. A. Plantas medicinais no Brasil: nativas e exóticas. Nova Odessa: Instituto Plantarum de Estudo da Flora, p. 544, 2002.

LUKHOBA, C. W.; SIMMONDS, M. S. J.; PATON, A. J. Plectranthus: A review fetch o botanical uses. Journal of Ethnopharmacology, v. 103, p. 1-24, 2006. https://doi.org/10.1016/j.jep.2005.09.011

MATTEI, D.; DIAS-ARIEIRA, C. R.; BIELA, F.; ROLDI, M.; SILVA, T. R. B.; RAMPIM, L.; DADAZIO, T. S.; TAVARES-SILVA, C. A. Essential oil of Rosmarinus officinalis in the control of Meloidogyne javanica and Pratylenchus brachyurus in soybean. Bioscience Journal, v. 30, p. 469-476, 2014.

MELO, E. A.; GUERRA, N. B. Ação antioxidante de compostos fenólicos naturalmente presentes em alimentos. Boletim Sociedade Brasileira de Ciência e Tecnologia de Alimentos. Campinas: v. 36, n. 1, p. 1$11,2002$.

OLIVEIRA, R. A.; SÁ, I. C. G.; DUARTE, L. P.; OLIVEIRA, F. F. Constituintes voláteis de Menthapulegium L. e Plectranthus amboinicus (Lour.) Spreng. Revista Brasileira de Plantas Medicinais, Botucatu, v. 13, n. 2, p. 165-169, 2011.

PINTO, A. C.; SILVA, D. H. S.; BOLZANI, V. S.; LOPES, N. P.; EPIFANIO, R. A. Produtos Naturais: Atualidades, Desafios e Perspectivas. Química Nova, v. 25, supl. 1, p. 45-61, 2002. https://doi.org/10.1590/S0100-40422002000800009

REIS, J. B. Estudo analítico, avaliação da toxicidade e atividade moluscicida do óleo essencial de Cinnamomum zeylanicum Blume (canela) frente ao caramujo Biomphalaria glabrata. (say,1818). 2012, 86 f. Dissertação (Mestrado). Universidade Federal do Maranhão, São Luís, 2012. 
RODRIGUES, F. F. G.; COSTA, J. G. M.; RODRIGUES, F. F. G.; CAMPOS, A. R. Study of the Interference between Plectranthus Species Essential Oils from Brazil and Aminoglycosides. Evidence-Based Complementary and Alternative Medicine, 2013. Disponível em: <http://dx.doi.org/10.1155/2012/724161>. Acesso em 18 Aug. 2015.

RUBERTO, G.; BARATTA, M. T. Antioxidant activity of selected assential oil components in two lipid model systems. Food Chemistry, v. 69, n. 2, p. 167-174, 2000. https://doi.org/10.1016/S0308-8146(99)00247-2

SANTOS, A. L. Comportamento de Staphyloccus aureus em queijo minas fabricado com leite cru. 2004. 54 p. Dissertação (Mestrado em ciências dos Alimentos) - Universidade Federal de Lavras, Lavras, 2004.

SILVA, F. F. M.; BERTINI, L. M.; ALVES, L. A.; MOURA, L. F.; BARBOSA, P. T.; FERNANDES, A. B. D. Análise da composição química do óleo essencial de Campim Santo (Cymbopogon citratus) obtido através de extrator por arraste a vapor d'água construído com materiais de fácil aquisição e baixo custo. Revista Holos, v. 4, p. 144-152, 2014. https://doi.org/10.15628/holos.2014.1762

SIMÃO, A. M. Aditivos para alimentos sob o aspecto toxicológico. São Paulo: Nobel, 1985.

ZHENG, W.; WANG, S. Y. Antioxidant activity and phenolic compounds in selected herbs. Journal of Agricultural and Food Chemistry. v. 49, p. 5165-5170, 2001. https://doi.org/10.1021/jf010697n 